\title{
Morphine use in cancer surgery
}

\section{Banafsheh Afsharimani, Peter J. Cabot and Marie-Odile Parat*}

School of Pharmacy, University of Queensland, Brisbane, QLD, Australia

Edited by:

François E. Paris, INSERM, France

Reviewed by:

François E. Paris, INSERM, France

Chantal Dessy, Université catholique

de Louvain, Belgium

*Correspondence:

Marie-Odile Parat, School of

Pharmacy, University of Queensland,

20 Cornwall Street, Brisbane, QLD

4012, Australia.

e-mail:m.parat@uq.edu.au
Morphine is the core of perioperative pain management. However, when it comes to cancer surgery the possibility that this drug might affect tumor recurrence and metastasis has raised concerns. The results of two recent retrospective clinical trials indicated that regional anesthesia/analgesia might be beneficial in prostate and breast cancer surgery. It was proposed that morphine could be responsible for the higher recurrence and mortality rate observed in the general anesthesia/opioid analgesia groups. Nevertheless, the results of several other retrospective studies and one randomized prospective trial failed to confirm any advantage for regional anesthesia/analgesia over general anesthesia and opioid analgesia. Moreover laboratory data on the effect of morphine on cancer are contradictory, ranging from tumor-promoting to anti-tumor effects. Considering that surgical stress and pain promote the recurrence and spread of cancer, choosing a proper analgesic strategy is of high significance. Although the question of whether morphine causes any harm to cancer patients remains unanswered, alternative analgesic regimens could be used concomitant to or instead of morphine to limit its potential adverse effects.

Keywords: morphine, regional, anesthesia, analgesia, cancer, surgery

\section{PERIOPERATIVE MORPHINE AND CANCER}

There has been increased interest surrounding the possibility that morphine should not be given perioperatively to cancer surgery patients. This followed two retrospective clinical studies showing that when regional (i.e., paravertebral or epidural) anesthesia/analgesia was used in patients undergoing surgery for either breast or prostate cancer, the rate of cancer recurrence, and/or metastasis was significantly lower than in patients undergoing general anesthesia with opioid analgesia. The follow-up period was 2.5-4 years for the breast cancer and 2.8-12.8 years for the prostate cancer study (Exadaktylos et al., 2006; Biki et al., 2008). One of the hypotheses proposed to explain these results has involved the opioid-sparing effect of regional anesthesia/analgesia, and the assumption that morphine could be at least in part responsible for the higher recurrence and mortality rate in the general anesthesia groups, which received opioid analgesia.

Opioids are a major class of drugs in pain management and morphine, as a potent agonist of the mu opioid receptor, is still the drug of choice from this family (Paice, 2003). The concerns regarding possible promoting effects of morphine on tumor growth and metastasis mostly originated from the fact that opioids, including morphine, have well-established immunosuppressive effects, compromising cellular and humoral immune function and thus host defense against malignancies (Ishikawa et al., 1993; Sacerdote et al., 2000; Franchi et al., 2007). In addition, morphine has recently been reported to increase angiogenesis, thereby supporting tumor growth in a breast cancer xenograft model in mice (Gupta et al., 2002). Further fueling the debate, opioids were shown to transactivate VEGF receptors, induce angiogenesis and promote vascular permeability (Singleton et al., 2006, 2007), and activation of opioid receptors was documented to enhance the proliferation and invasion of lung cancer cells (Mathew et al., 2011).
Whilst these reports are convincing and the question of whether morphine should be avoided in cancer surgery patients legitimate, it must be kept in mind that the reported tumor-promoting effect of opioids is balanced by their anti-tumor potential, documented at various levels (Table 1). Morphine has also been shown to have direct anti-proliferative and pro-apoptotic effects on different cancer cells (Maneckjee et al., 1990; Maneckjee and Minna, 1994; Hatzoglou et al., 1996; Sueoka et al., 1998; Tegeder et al., 2003; Zagon and Mclaughlin, 2003). Furthermore, several studies using endothelial cells (Balasubramanian et al., 2001; Lam et al., 2008; Hsiao et al., 2009), chorioallantoic membranes (Pasi et al., 1991; Blebea et al., 2000), in vitro capillary tube formation assay or implanted matrigel plugs (Lam et al., 2008; Martin et al., 2010a,b), and in vivo tumor assays (Koodie et al., 2010; Ustun et al., 2010), have demonstrated angiostatic effects for morphine. However there is no clinical study demonstrating the effect of morphine per se on tumor growth, recurrence or metastasis. Postoperative pain management is of high significance especially in cancer patients. Failure to properly control postoperative pain, results in an exacerbated, and prolonged stress response, which increases the risk of tumor spread in the postoperative period (Page et al., 2001). The highly effective analgesic effect of opioids is suggested to be beneficial in reducing the surgical stress (Yeager and Colacchio, 1991; Page et al., 1993, 1998; Sasamura et al., 2002). Therefore, if morphine analgesia is to be avoided in the perioperative period in cancer surgery patients, effective alternative strategies should imperatively be adopted to effectively control postoperative pain. These include (i) the use of regional anesthesia/analgesia, (ii) the co-administration with morphine of a peripheral opioid antagonist, or (iii) alternate analgesic interventions. 
Table 1 |The effect of morphine administration on tumor progression in animal models.

\begin{tabular}{|c|c|c|c|}
\hline Animal model & Type of cells & $\begin{array}{l}\text { Impact of morphine administration } \\
\text { on Tumor progression }\end{array}$ & Reference \\
\hline $\begin{array}{l}\text { I.V. injection of tumor cells to } \\
\text { rats }\end{array}$ & MADB106 lung tumor cells & $\begin{array}{l}\text { Increase of lung diffusion of tumor cells in } \\
\text { the presence of surgical stress }\end{array}$ & Franchi et al. (2007) \\
\hline $\begin{array}{l}\text { S.C./l.P. injection of tumor } \\
\text { cells to mice }\end{array}$ & $\begin{array}{l}\text { EL-4 leukemia } \\
\text { Sarcoma } 180 \text { carcinoma } \\
\text { P388 leukemia } \\
\text { Meth-A sarcoma }\end{array}$ & $\begin{array}{l}\text { Increase in the weight of solid tumors and } \\
\text { increased mortality caused by ascite-type } \\
\text { tumors }\end{array}$ & Ishikawa et al. (1993) \\
\hline $\begin{array}{l}\text { Matrigel plugs and breast } \\
\text { xenografts in mice }\end{array}$ & MCF-7 breast cancer cell & Increase in tumor size and angiogenesis & Gupta et al. (2002) \\
\hline $\begin{array}{l}\text { I.V. injection of tumor cells to } \\
\text { mice }\end{array}$ & 26-L5 colon carcinoma cells & $\begin{array}{l}\text { Decrease in the number of metastatic } \\
\text { colonies in lungs }\end{array}$ & Harimaya et al. (2002) \\
\hline $\begin{array}{l}\text { Tumor cell-containing matrigel } \\
\text { plugs in mice }\end{array}$ & $\begin{array}{l}\text { Mouse Lewis lung carcinoma } \\
\text { cells }\end{array}$ & Reduction in tumor cell-induced angiogenesis & Koodie et al. (2010) \\
\hline S.C. tumor xenografts in mice & Ehrlich ascites & $\begin{array}{l}\text { Inhibition of tumor growth via suppression of } \\
\text { tumor angiogenesis and increased tumor cell } \\
\text { apoptosis }\end{array}$ & Ustun et al. (2010) \\
\hline $\begin{array}{l}\text { I.V. inoculation of tumor cells } \\
\text { to rats }\end{array}$ & MADB106 breast cancer cells & $\begin{array}{l}\text { Inhibition of surgery-induced increase in } \\
\text { metastatic localization of tumor cells in lungs }\end{array}$ & Page et al. (1993, 1994, 1998) \\
\hline $\begin{array}{l}\text { I.V. injection of tumor cells to } \\
\text { rats by laparotomy }\end{array}$ & Colon adenocarcinoma cells & $\begin{array}{l}\text { Decrease in the incidence and burden of } \\
\text { metastatic tumors in the liver }\end{array}$ & Yeager and Colacchio (1991) \\
\hline $\begin{array}{l}\text { I.V. injection of tumor cells to } \\
\text { rats with laparotomy }\end{array}$ & Colon adenocarcinoma cells & $\begin{array}{l}\text { Increase in the incidence and burden of } \\
\text { metastatic tumors in the liver }\end{array}$ & Colacchio et al. (1994) \\
\hline $\begin{array}{l}\text { Tumor cell inoculation into } \\
\text { hind paw of mice }\end{array}$ & B16-BL6 melanoma cells & $\begin{array}{l}\text { Decrease in tumor growth and the number of } \\
\text { metastatic nodules in the lungs } 2 \text { weeks } \\
\text { after tumor excision }\end{array}$ & Sasamura et al. (2002) \\
\hline $\begin{array}{l}\text { S.C. injection of tumor cells in } \\
\text { the right hind thigh }\end{array}$ & $\begin{array}{l}\text { SCK mammary carcinoma } \\
\text { cells }\end{array}$ & $\begin{array}{l}\text { Increase in tumor angiogenesis } \\
\text { Increase in tumor weight as well as } \\
\text { incidence and burden of lung metastases }\end{array}$ & Farooqui et al. (2007) \\
\hline $\begin{array}{l}\text { I.V. injection of tumor cells to } \\
\text { rats } 4-5 \mathrm{~h} \text { after induction of } \\
\text { anesthesia (morphine } \\
\text { administration) for laparotomy }\end{array}$ & $\begin{array}{l}\text { MADB106 mammary } \\
\text { adenocarcinoma cells }\end{array}$ & $\begin{array}{l}\text { Attenuation of surgery-induced surge in lung } \\
\text { retention of tumor cells } 24 \mathrm{~h} \text { after tumor cell } \\
\text { injection } \\
\text { No significant effect on the number of } \\
\text { metastatic colonies in lungs after } 3 \text { weeks }\end{array}$ & Bar-Yosef et al. (2001) \\
\hline $\begin{array}{l}\text { S.C. injection of tumor cells to } \\
\text { mice }\end{array}$ & $\begin{array}{l}\text { MCF-7 and MDA-MB231 } \\
\text { breast cancer cells } \\
\text { HT-29 colon cancer cells }\end{array}$ & $\begin{array}{l}\text { Smaller volume of MCF-7 and MDA-MB231 } \\
\text { tumors compared to control groups } \\
\text { No effect on the size of HT-29 tumors }\end{array}$ & Tegeder et al. (2003) \\
\hline
\end{tabular}

\section{REGIONAL ANESTHESIA AND ANALGESIA}

In animal models it has been demonstrated that epidural or spinal blockade results in a reduction of the immune suppression after surgery and protection against postoperative metastasis (Bar-Yosef et al., 2001; Wada et al., 2007). Recent retrospective studies have been conducted to unveil potential significant differences in cancer recurrence and or metastasis after surgery with regional or general anesthesia. Two retrospective studies on breast and prostate cancer showed that cancer recurrence rate was lower when general anesthesia was supplemented with regional (i.e., epidural or paravertebral) anesthesia. Exadaktylos et al. (2006) studied the medical history of 129 patients that had undergone mastectomy for primary breast cancer and found lower cancer recurrence and metastasis $\sim 2.5$ years after surgery in patients that received paravertebral anesthesia with general anesthesia compared to those that had received general anesthesia alone (Exadaktylos et al., 2006). Similarly Biki et al. (2008) showed that in radical prostatectomy, using epidural anesthesia and analgesia was associated with a lower risk of biochemical cancer recurrence, identified as a postoperative increase in prostate-specific antigen (PSA), in a follow-up period of 2.8-12.8 years (Biki et al., 2008). In a partly supporting study, epidural anesthesia/analgesia complementary to general anesthesia was found to be associated with a longer survival rate in patients with non-metastatic (but not metastatic) colon cancer (Christopherson et al., 2008). However, other retrospective studies failed to show any benefits for regional anesthesia/analgesia regarding recurrence and mortality rate after surgery for prostate, colorectal, and cervical cancers even though it reduced the need for postoperative systemic opioid administration (Gottschalk et al., 2010a; Ismail et al., 2010; Tsui et al., 2010). 
Clearly, and as acknowledged by the authors, retrospective studies suffer from a high rate of selection and confounding biases. Furthermore, these studies were designed to test different anesthesia and analgesia regimens rather than the effect of morphine, and the existence of multiple uncontrolled variables in the two groups made it difficult to attribute the observed results to morphine administration as an independent factor.

Samples from patients given general anesthesia with regional anesthesia/analgesia or opioid analgesia for cancer surgery have also been investigated for pro- or anti-tumor effects in vitro. Serum from patients of a prospective study, treated with a combination of general anesthesia with paravertebral anesthesia/analgesia, increased the proliferation but not the migration of cultured MCF7 breast cancer cells when compared to general anesthesia and opioid analgesia group (Deegan et al., 2009). Furthermore, the postoperative serum concentration of pro-tumor cytokines, IL-1 $\beta$ and IL-8, and of the pro-angiogenic factor VEGF-C were considerably lower while anti-tumor cytokine, IL-8 was higher in breast cancer surgery patients treated with paravertebral anesthesia and analgesia rather than general anesthesia and opioid analgesia (Deegan et al., 2010; Looney et al., 2010).

The only prospective study with finalized and published results testing the effect of anesthesia and pain management on cancer recurrence and mortality is a multicenter randomized, controlled clinical trial performed in Australia, New Zealand, and Asia. In this study 503 patients undergoing major abdominal surgery for cancer, mostly colon cancer, were randomly assigned to receive general anesthesia with either epidural anesthesia and analgesia, or postoperative intravenous opioid analgesia. The results showed no significant difference in cancer recurrence and mortality at 23 years between the two groups (Myles et al., 2011), confirming the relative lack of effect seen with colon cancer in retrospective studies (Christopherson et al., 2008). The results of these clinical studies are summarized in Table 2. Several randomized controlled clinical trials are still in progress to assess the possible effect of anesthetic technique on the course of cancer, which might be tumor site-specific. These studies are following up the recurrence, metastasis, and mortality rates in patients randomized to receive either general or regional anesthesia/analgesia for surgical removal of different types of cancer in multiple clinical centers (Gottschalk et al., 2010b; Afsharimani et al., 2011). Whether a simple modification of the anesthetic technique and postoperative pain management can improve survival of cancer surgery patients is a highly important question awaiting the results of these prospective trials.

\section{MU OPIOID RECEPTOR ANTAGONISTS}

Considering the possibility that morphine might have direct effects on tumor growth, (as opposed to centrally ablating of the stress response), the co-administration of a peripheral antagonist capable of reversing the unwanted peripheral effects of morphine without affecting its central analgesic properties is an attractive option.

This hypothesis has been tested in several experimental settings. An in vitro study showed that pre-treatment of cultured human endothelial cells with methylnaltrexone reversed the proliferation- and migration-inducing effects of morphine and other opioid agonists (Singleton et al., 2006). Furthermore, in vitro and in vivo evidence were documented showing that methylnaltrexone inhibits the disruption of endothelial cell barrier and the increased vascular permeability induced by mu receptor agonists, thrombin or lipopolysaccharide (Singleton et al., 2007). As a result, methylnaltrexone was suggested to have potential therapeutic applications in controlling tumor angiogenesis. Methylnaltrexone was further shown to have synergistic effects on the anti-angiogenic effect of the anti-cancer drugs bevacizumab, 5fluorouracil, rapamycin, and temsirolimus (Singleton et al., 2008, 2010). Results also demonstrated the involvement of mu opioid receptors in the proliferation and migration of lung cancer cells. Naltrexone as well as MOR knockdown attenuated tumor cell growth and invasion and prevented tumor growth and invasion in vitro and metastasis in mice. Interestingly tumors did not develop in MOR knockout mice to which lung tumor cells where injected (Mathew et al., 2011). Moreover, the opioid antagonist naloxone decreased 17beta-estradiol-induced proliferation of MCF-7 breast cancer cells by $65 \%$, due to antagonism of either $\mathrm{Mu}$ opioid or estrogen receptors (Farooqui et al., 2006). Currently, a phase II clinical trial is recruiting subjects to study the possible anti-tumor effects of naltrexone tablets, on estrogen-dependent breast cancer (clinicaltrials.gov using the search words opioid antagonist cancer). However, a retrospective clinical study of patients under methadone maintenance therapy failed to show any advantage of naltrexone compared to methadone in the formation of new cancers (Singleton and Moss, 2010).

The potential use of opioid antagonists in the context of cancer is debatable in view of contrasting literature: naltrexone was shown to increase the proliferation of colon, pancreatic, and head and neck cancer cells in vitro. This effect was suggested to be due to antagonism of the growth inhibiting effect of endogenous opioid [Met5] enkephalin (Zagon et al., 1996, 2000). Moreover, in a chorioallantoic membrane assay, anti-angiogenic effects of up to $50 \%$ were observed for naltrexone (Blebea et al., 2000). Accordingly, a study on angiogenesis during cholestasis in rats showed naltrexone to promote angiogenesis in the liver tissue (Faramarzi et al., 2009). Further studies, including randomized controlled clinical trials, would shed light on whether peripheral opioid antagonists improve cancer free survival when added to opioid analgesia after cancer surgery.

\section{ALTERNATIVE ANALGESIC INTERVENTIONS}

Alternative pain-relieving drugs devoid of immunosuppressive effect have been proposed to replace morphine in the postoperative pain management of cancer surgery patients. These include other opioids than morphine, non-steroidal anti-inflammatory drugs (NSAIDs), and adrenergic-active drugs.

Fentanyl and its derivatives sufentanil and remifentanil are highly lipophilic and potent mu receptor agonists, widely used in anesthesia (Forget and De Kock, 2009). While some studies show that these drugs lack the immunosuppressive effects of morphine (Bilfinger et al., 1998; Yeager et al., 2002; Akural et al., 2004), several lines of evidence denoted suppressed cellular immune function and increased risk of metastasis with their perioperative administration (Beilin et al., 1996; Sacerdote et al., 2001; Shavit et al., 2004). Partial agonists such as buprenorphine have been suggested 
Table 2 |The effect of perioperative anesthetic/analgesic technique on cancer recurrence and survival.

\begin{tabular}{|c|c|c|c|c|}
\hline Type of study & Surgical procedure & $\begin{array}{l}\text { Anesthetic/analgesic } \\
\text { regimen }\end{array}$ & $\begin{array}{l}\text { Effect on the course } \\
\text { of cancer }\end{array}$ & Reference \\
\hline $\begin{array}{l}\text { Retrospective clinical } \\
\text { study }\end{array}$ & $\begin{array}{l}\text { Mastectomy for primary } \\
\text { breast cancer }\end{array}$ & $\begin{array}{l}\mathrm{GA}+\mathrm{PVA}(n=50) \\
\mathrm{GA}+\operatorname{PCA}(n=79)\end{array}$ & $\begin{array}{l}\text { Lower cancer recurrence or } \\
\text { metastases in patients receiving } \\
\text { PVA + GA }\end{array}$ & Exadaktylos et al. (2006) \\
\hline $\begin{array}{l}\text { Retrospective clinical } \\
\text { study }\end{array}$ & $\begin{array}{l}\text { Open radical } \\
\text { prostatectomy for invasive } \\
\text { prostate cancer }\end{array}$ & $\begin{array}{l}\mathrm{GA}+\mathrm{EA}(n=102) \\
\mathrm{GA}+\text { Opioid analgesia } \\
(n=123)\end{array}$ & $\begin{array}{l}\text { Lower risk of biochemical cancer } \\
\text { recurrence in patients receiving } \\
\text { EA }\end{array}$ & Biki et al. (2008) \\
\hline $\begin{array}{l}\text { Retrospective clinical } \\
\text { study }\end{array}$ & Resection of colon cancer & $\begin{array}{l}\mathrm{GA}+\mathrm{IV} \text { opioids }(n=92) \\
\mathrm{GA}+\mathrm{EA}(n=85)\end{array}$ & $\begin{array}{l}\text { Higher survival rate in patients } \\
\text { with non-metastatic, but not } \\
\text { metastatic colon cancer }\end{array}$ & Christopherson et al. (2008) \\
\hline $\begin{array}{l}\text { Secondary analysis of } \\
\text { subjects of a } \\
\text { randomized controlled } \\
\text { clinical trial }\end{array}$ & $\begin{array}{l}\text { Radical prostatectomy for } \\
\text { prostate cancer }\end{array}$ & $\begin{array}{l}\mathrm{GA}+\mathrm{EA}(n=49) \\
\mathrm{GA}+\mathrm{IV} \text { morphine }(n=50)\end{array}$ & $\begin{array}{l}\text { No difference between the } \\
\text { group receiving epidural } \\
\text { anesthesia and control groups }\end{array}$ & Tsui et al. (2010) \\
\hline $\begin{array}{l}\text { Retrospective clinical } \\
\text { study }\end{array}$ & Colorectal cancer surgery & $\begin{array}{l}\mathrm{GA}+\mathrm{EA}(n=256) \\
\mathrm{GA}(n=253)\end{array}$ & $\begin{array}{l}\text { No difference in cancer } \\
\text { recurrence rate in normal } \\
\text { subjects } \\
\text { Lower cancer recurrence rate } \\
\text { with EA in subjects older than } \\
64 \text { year }\end{array}$ & Gottschalk et al. (2010a) \\
\hline $\begin{array}{l}\text { Retrospective clinical } \\
\text { study }\end{array}$ & $\begin{array}{l}\text { Brachytherapy for cervical } \\
\text { cancer }\end{array}$ & $\begin{array}{l}\text { Neuraxial anesthesia (SA/EA) } \\
(n=63) \\
\mathrm{GA}(n=69)\end{array}$ & $\begin{array}{l}\text { No difference in tumor } \\
\text { recurrence and mortality rate } \\
\text { between the two groups }\end{array}$ & Ismail et al. (2010) \\
\hline $\begin{array}{l}\text { Prospective, } \\
\text { randomized, controlled } \\
\text { clinical trial }\end{array}$ & $\begin{array}{l}\text { Excision of cancer by } \\
\text { major abdominal surgery } \\
\text { such as esophagectomy, } \\
\text { gastrectomy, hepatectomy, } \\
\text { pancreatectomy, } \\
\text { colectomy, nephrectomy, } \\
\text { cystectomy, radical } \\
\text { hysterectomy, and open } \\
\text { prostatectomy }\end{array}$ & $\begin{array}{l}\mathrm{GA}+\mathrm{EA}(n=230) \\
\mathrm{GA}+\mathrm{IV} \text { opioids }(n=216)\end{array}$ & $\begin{array}{l}\text { No difference in long-term } \\
\text { cancer recurrence and mortality } \\
\text { after major abdominal surgery }\end{array}$ & Myles et al. (2011) \\
\hline $\begin{array}{l}\text { Retrospective Clinical } \\
\text { study }\end{array}$ & $\begin{array}{l}\text { Primary excision of } \\
\text { cutaneous melanoma }\end{array}$ & $\begin{array}{l}\text { Local anesthesia }(n=2185) \\
\mathrm{GA}(n=2136)\end{array}$ & $\begin{array}{l}\text { Slightly increased risk of } \\
\text { mortality in patients receiving } \\
\text { general anesthesia compared to } \\
\text { local anesthesia }\end{array}$ & Schlagenhauff et al. (2000) \\
\hline In vitro & $\begin{array}{l}\text { Mastectomy for breast } \\
\text { cancer patients }\end{array}$ & $\begin{array}{l}\mathrm{GA}+\mathrm{PVA}(n=15) \\
\mathrm{GA}+\text { opioid analgesia }(n=15)\end{array}$ & $\begin{array}{l}\text { Reduced surgical stress } \\
\text { response with PVA } \\
\text { No difference in pro-angiogenic } \\
\text { factors VEGF and PGE2 }\end{array}$ & O'Riain et al. (2005) \\
\hline In vitro & Breast cancer surgery & $\begin{array}{l}\text { Propofol/PVA }(n=11) \\
\text { GA }+ \text { opioid analgesia }(n=11)\end{array}$ & $\begin{array}{l}\text { Serum from patients receiving } \\
\text { propofol/PVA inhibited } \\
\text { proliferation, but not migration, } \\
\text { of breast cancer cells in vitro }\end{array}$ & Deegan et al. (2009) \\
\hline In vitro & $\begin{array}{l}\text { Primary breast cancer } \\
\text { surgery }\end{array}$ & $\begin{array}{l}\text { Propofol/PVA }(n=15) \\
\text { GA }+ \text { opioid analgesia }(n=17)\end{array}$ & $\begin{array}{l}\text { Propofol/PVA alters some but not } \\
\text { all cytokines and MMPs in favor } \\
\text { of resistance against cancer } \\
\text { progression and metastasis }\end{array}$ & Deegan et al. (2010) \\
\hline In vitro & $\begin{array}{l}\text { Primary breast cancer } \\
\text { surgery }\end{array}$ & $\begin{array}{l}\text { Propofol/PVA }(n=20) \\
\text { GA }+ \text { morphine analgesia } \\
(n=20)\end{array}$ & $\begin{array}{l}\text { Decreased postoperative serum } \\
\text { concentrations of VEGF-C and } \\
\text { increased TGF- } \beta \text { in patients } \\
\text { receiving propofol/PVA }\end{array}$ & Looney et al. (2010) \\
\hline
\end{tabular}

GA, general anesthesia; PVA, paravertebral anesthesia; PCA, patient-controlled analgesia; EA, epidural anesthesia, SA, spinal anesthesia. 
as a replacement for morphine and fentanyl, based on animal data showing buprenorphine is devoid of immunosuppressive effects and protects against surgery-induced increased metastasis (Franchi et al., 2007). Tramadol is a low-affinity mu opioid receptor agonist with complementary central inhibition of serotonin and noradrenaline reuptake (Leppert, 2009). Tramadol not only improved immune function in animals (Sacerdote et al., 1999; Tsai and Won, 2001) but also reduced postoperative immunosuppression in patients undergoing surgery for uterine carcinoma, while providing analgesic efficacy comparable to that of morphine (Vickers and Paravicini, 1995; Stamer et al., 1997; Hopkins et al., 1998; Sacerdote et al., 2000; Hadi et al., 2006).

Non-steroidal anti-inflammatory drugs administration has different side effects and considerably lower risk of tolerance than morphine (Anonymous, 1991). NSAIDs with different modes of administration have significant opioid-sparing effects and improve post-surgical pain in different types of surgery. In minor and intermediate surgical procedures they could be considered as alternatives to opioids (Cashman et al., 1985; Anonymous, 1991; Murphy, 1993). NSAIDs further help to improve immune function and host defense against malignant cells (Forget et al., 2010). In addition, because cyclooxygenases (COX) I and II, catalyze the formation of prostaglandins, which are involved in tumor formation, growth, angiogenesis and invasion, NSAIDs and COX inhibitors, particularly COX-2 inhibitors, offer a potential benefit in cancer therapy (Méric et al., 2006). It was demonstrated that adding celecoxib, a selective COX-2 inhibitor, to morphine, reduces the morphine-induced increase in prostaglandin secretion and angiogenesis, growth and metastasis of breast tumor in rodents (Farooqui et al., 2007; Benish et al., 2008). In a murine model of surgery-induced cellular immunosuppression, perioperative administration of the injectable NSAID ketorolac protected, while morphine decreased, the natural killer (NK) cell activity after laparotomy (Colacchio et al., 1994). In a recent retrospective analysis of breast cancer surgery patients, preoperative administration of ketorolac was shown to be associated with lower cancer recurrence while other drugs, namely sufentanil, ketamine, and clonidine, failed to show such beneficial effect (Forget et al., 2010).

Other strategies to assist in controlling postoperative pain and reduce the need for opioid analgesics include systemic administration of glucocorticoids (Salerno and Hermann, 2006; Romundstad and Stubhaug, 2007; Dahl et al., 2010), local infiltration of anesthetics such as lidocaine which was moderately and transiently beneficial in controlling acute pain after abdominal surgery (Dahl et al., 2010), or beta blockers which via catecholamine inhibition may enhance the immune function and prevent cancer progression (Palm et al., 2006). Several studies have shown that intraoperative infusion of beta blockers, and particularly the $\beta 1$-blocker, esmolol, decreases the intra- and post-operative use of opioids (Johansen et al., 1998; White et al., 2003; Chia et al., 2004; Collard

\section{REFERENCES}

Anonymous. (1991). Postoperative pain relief and non-opioid analgesics. Lancet 337, 524-526.

Afsharimani, B., Cabot, P., and Parat, M. O. (2011). Morphine and tumor growth and metastasis. Cancer Metastasis Rev. 30, 225-238.

Akural, E. I., Salomaki, T. E., Bloigu, A. H., Ryhanen, P., Tekay, A. H., Alahuhta, S. M., and Surcel, H. M. (2004). The effects of

et al., 2007). Moreover, beta blockers have synergistic effects with COX-2 inhibitors, preserving the immune function after surgery, and reducing the risk of postoperative metastasis in rats (Benish et al., 2008). However safety studies, particularly in patients susceptible to risks associated with hypotension, are required (Yu et al., 2011). Currently a randomized clinical trial is testing the ability of intravenous esmolol to enhance postoperative pain relief and reduce the need for intraoperative opioids in patients undergoing laparoscopic prostatectomy and upper gastrointestinal surgery (clinicaltrials.gov using the search words beta-blocker cancer surgery).

Another intervention on the adrenergic system with possible opioid-sparing effect would be $\alpha-2$ adrenergic receptor activation. The antihypertensive drug clonidine is used preoperatively to prolong regional anesthesia and reduces the need for systemic anesthetics and postoperative opioid analgesics (Pyati and Gan, 2007). However due to its multiple side effects such as excessive hypotension, sedation, and bradycardia its use is limited to regional administration (Buvanendran and Kroin, 2009). Moreover, clonidine and dexmedetomidine, another $\alpha 2$-agonist used in the intensive care unit, were shown to enhance breast tumor growth in a mouse model, possibly via enhanced breast tumor cell proliferation and apoptosis inhibition (Bruzzone et al., 2008).

The anti-convulsant drug gabapentin has also been proposed to reduce acute postoperative pain and the need for opioid administration. This beneficial effect of gabapentin has been confirmed by several randomized controlled clinical trials in oncological and non-oncological surgeries (Eckhardt et al., 2000; Dirks et al., 2002; Fassoulaki et al., 2002; Mathiesen et al., 2007). Pregabalin, another derivative of this family has also been suggested to have opioid-sparing effects, however the results of clinical trials on its dose-dependent efficacy are inconsistent and its use in perioperative pain management still questionable (Dahl et al., 2010). While these drugs are proven to alleviate pain immediately after surgery, the long-term outcome of their administration is unknown (Tiippana et al., 2007). Moreover, although they significantly reduce the postoperative side effects of opioids such as nausea, vomiting, and urinary retention, they aggravate sedation to a great extent (Tiippana et al., 2007; Dahl et al., 2010).

In conclusion, laboratory data available at the moment do not draw a clear picture of morphine as a tumor-promoting or inhibiting agent. The first prospective trial testing whether regional anesthesia and analgesia improved cancer recurrence and metastasis has not confirmed the promising conclusions drawn from retrospective studies, however further prospective trials are still ongoing as the effect may be cancer type specific. Even if these prospective trials were to show a benefit to cancer patients in using regional analgesia and anesthesia and reduced opioid postoperative analgesia, the role of opioids per se would not be demonstrated.

pre-emptive epidural sufentanil on human immune function. Acta Anaesthesiol. Scand. 48, 750-755.

Balasubramanian, S., Ramakrishnan, S., Charboneau, R., Wang, J., Barke, R. A., and Roy, S.
(2001). Morphine sulfate inhibits hypoxia-induced vascular endothelial growth factor expression in endothelial cells and cardiac myocytes. J. Mol. Cell. Cardiol. 33, 2179-2187. 
Bar-Yosef, S., Melamed, R., Page, G. G., Shakhar, G., Shakhar, K., and Ben-Eliyahu, S. (2001). Attenuation of the tumor-promoting effect of surgery by spinal blockade in rats. Anesthesiology 94, 1066-1073.

Beilin, B., Shavit, Y., Hart, J., Mordashov, B., Cohn, S., Notti, I., and Bessler, H. (1996). Effects of anesthesia based on large versus small doses of fentanyl on natural killer cell cytotoxicity in the perioperative period. Anesth. Analg. 82, 492-497.

Benish, M., Bartal, I., Goldfarb, Y., Levi, B., Avraham, R., Raz, A., and Ben-Eliyahu, S. (2008). Perioperative use of beta-blockers and COX2 inhibitors may improve immune competence and reduce the risk of tumor metastasis. Ann. Surg. Oncol. 15, 2042-2052.

Biki, B., Mascha, E., Moriarty, D. C., Fitzpatrick, J. M., Sessler, D. I., and Buggy, D. J. (2008). Anesthetic technique for radical prostatectomy surgery affects cancer recurrence: a retrospective analysis. Anesthesiology 109, 180-187.

Bilfinger, T. V., Fimiani, C., and Stefano, G. B. (1998). Morphine's immunoregulatory actions are not shared by fentanyl. Int. J. Cardiol. 64(Suppl. 1), S61-S66.

Blebea, J., Mazo, J. E., Kihara, T. K., $\mathrm{Vu}$, J. H., Mclaughlin, P. J., Atnip, R. G., and Zagon, I. S. (2000). Opioid growth factor modulates angiogenesis. J. Vasc. Surg. 32, 364-373.

Bruzzone, A., Pinero, C. P., Castillo, L. F., Sarappa, M. G., Rojas, P., Lanari, C., and Luthy, I. A. (2008). Alpha2-adrenoceptor action on cell proliferation and mammary tumour growth in mice. Br. J. Pharmacol. $155,494-504$.

Buvanendran, A., and Kroin, J. S. (2009). Multimodal analgesia for controlling acute postoperative pain. Curr. Opin. Anaesthesiol. 22, 588-593.

Cashman, J. N., Jones, R. M., Foster, J. M., and Adams, A. P. (1985). Comparison of infusions of morphine and lysine acetyl salicylate for the relief of pain after surgery. $\mathrm{Br}$. J. Anaesth. 57, 255-258.

Chia, Y. Y., Chan, M. H., Ko, N. H., and Liu, K. (2004). Role of betablockade in anaesthesia and postoperative pain management after hysterectomy. Br. J. Anaesth. 93, 799-805.

Christopherson, R., James, K. E., Tableman, M., Marshall, P., and Johnson, F. E. (2008). Long-term survival after colon cancer surgery: a variation associated with choice of anesthesia. Anesth. Analg. 107, 325-332.
Colacchio, T. A., Yeager, M. P., and Hildebrandt, L. W. (1994). Perioperative immunomodulation in cancer surgery. Am. J. Surg. 167, 174-179.

Collard, V., Mistraletti, G., Taqi, A., Asenjo, J. F., Feldman, L. S., Fried, G. M., and Carli, F. (2007). Intraoperative esmolol infusion in the absence of opioids spares postoperative fentanyl in patients undergoing ambulatory laparoscopic cholecystectomy. Anesth. Analg. 105, 1255-1262.

Dahl, J. B., Mathiesen, O., and Kehlet, H. (2010). An expert opinion on postoperative pain management, with special reference to new developments. Expert Opin. Pharmacother. 11, 2459-2470.

Deegan, C. A., Murray, D., Doran, P., Ecimovic, P., Moriarty, D. C., and Buggy, D. J. (2009). Effect of anaesthetic technique on oestrogen receptor-negative breast cancer cell function in vitro. Br. J. Anaesth. 103, 685-690.

Deegan, C. A., Murray, D., Doran, P., Moriarty, D. C., Sessler, D. I., Mascha, E., Kavanagh, B. P., and Buggy, D. J. (2010). Anesthetic technique and the cytokine and matrix metalloproteinase response to primary breast cancer surgery. Reg. Anesth. Pain Med. 35, 490-495.

Dirks, J., Fredensborg, B. B., Christensen, D., Fomsgaard, J. S., Flyger, H., and Dahl, J. B. (2002). A randomized study of the effects of single-dose gabapentin versus placebo on postoperative pain and morphine consumption after mastectomy. Anesthesiology 97, 560-564.

Eckhardt, K., Ammon, S., Hofmann, U., Riebe, A., Gugeler, N., and Mikus, G. (2000). Gabapentin enhances the analgesic effect of morphine in healthy volunteers. Anesth. Analg. 91 , 185-191.

Exadaktylos, A. K., Buggy, D. J., Moriarty, D. C., Mascha, E., and Sessler, D. I. (2006). Can anesthetic technique for primary breast cancer surgery affect recurrence or metastasis? Anesthesiology 105, 660-664.

Faramarzi, N., Abbasi, A., Tavangar, S. M., Mazouchi, M., and Dehpour, A. R. (2009). Opioid receptor antagonist promotes angiogenesis in bile duct ligated rats. J. Gastroenterol. Hepatol. 24, 1226-1229.

Farooqui, M., Geng, Z. H., Stephenson, E. J., Zaveri, N., Yee, D., and Gupta, K. (2006). Naloxone acts as an antagonist of estrogen receptor activity in MCF-7 cells. Mol. Cancer Ther. 5, 611-620.

Farooqui, M., Li, Y., Rogers, T., Poonawala, T., Griffin, R. J., Song, C. W., and Gupta, K. (2007).
COX-2 inhibitor celecoxib prevents chronic morphine-induced promotion of angiogenesis, tumour growth, metastasis and mortality, without compromising analgesia. Br. J. Cancer 97, 1523-1531.

Fassoulaki, A., Patris, K., Sarantopoulos, C., and Hogan, Q. (2002). The analgesic effect of gabapentin and mexiletine after breast surgery for cancer. Anesth. Analg. 95, 985-991.

Forget, P., and De Kock, M. (2009). Could anaesthesia, analgesia and sympathetic modulation affect neoplasic recurrence after surgery? A systematic review centred over the modulation of natural killer cells activity. Ann. Fr. Anesth. Reanim. 28, 751-768.

Forget, P., Vandenhende, J., Berliere, M., Machiels, J.-P., Nussbaum, B. Legrand, C., and De Kock, M. (2010). Do intraoperative analgesics influence breast cancer recurrence after mastectomy? A retrospective analysis. Anesth. Analg. 110, 1630-1635.

Franchi, S., Panerai, A. E., and Sacerdote, P. (2007). Buprenorphine ameliorates the effect of surgery on hypothalamus-pituitary-adrenal axis, natural killer cell activity and metastatic colonization in rats in comparison with morphine or fentanyl treatment. Brain Behav. Immun. 21, 767-774.

Gottschalk, A., Ford, J. G., Regelin, C. C., You, J., Mascha, E. J., Sessler, D. I., Durieux, M. E., and Nemergut, E. C. (2010a). Association between epidural analgesia and cancer recurrence after colorectal cancer surgery. Anesthesiology 113, 27-34.

Gottschalk, A., Sharma, S., Ford, J., Durieux, M. E., and Tiouririne, M. (2010b). Review article: the role of the perioperative period in recurrence after cancer surgery. Anesth. Analg. 110, 1636-1643.

Gupta, K., Kshirsagar, S., Chang, L., Schwartz, R., Law, P. Y., Yee, D. and Hebbel, R. P. (2002). Morphine stimulates angiogenesis by activating proangiogenic and survivalpromoting signaling and promotes breast tumor growth. Cancer Res. 62 , 4491-4498.

Hadi, M. A., Kamaruljan, H. S., Saedah, A., and Abdullah, N. M. (2006). A comparative study of intravenous patient-controlled analgesia morphine and tramadol in patients undergoing major operation. Med. J. Malaysia 61, 570-576.

Harimaya, Y., Koizumi, K., Andoh, T., Nojima, H., Kuraishi, Y., and Saiki, I. (2002). Potential ability of morphine to inhibit the adhesion, invasion and metastasis of metastatic colon 26L5 carcinoma cells. Cancer Lett. 187 121-127.

Hatzoglou, A., Bakogeorgou, E., and Castanas, E. (1996). The antiproliferative effect of opioid receptor agonists on the T47D human breast cancer cell line, is partially mediated through opioid receptors. Eur. J. Pharmacol. 296, 199-207.

Hopkins, D., Shipton, E. A., Potgieter, D., Van Dermerwe, C. A., Boon, J., De Wet, C., and Murphy, J. (1998). Comparison of tramadol and morphine via subcutaneous PCA following major orthopaedic surgery. Can. J. Anaesth. 45, 435-442.

Hsiao, P.-N., Chang, M.-C., Cheng, W.F., Chen, C.-A., Lin, H.-W., Hsieh, C.-Y., and Sun, W.-Z. (2009). Morphine induces apoptosis of human endothelial cells through nitric oxide and reactive oxygen species pathways. Toxicology 256, 83-91.

Ishikawa, M., Tanno, K., Kamo, A., Takayanagi, Y., and Sasaki, K. (1993). Enhancement of tumor growth by morphine and its possible mechanism in mice. Biol. Pharm. Bull. 16, 762-766.

Ismail, H., Ho, K. M., Narayan, K., and Kondalsamy-Chennakesavan, $\mathrm{S}$ (2010). Effect of neuraxial anaesthesia on tumour progression in cervical cancer patients treated with brachytherapy: a retrospective cohort study. Br. J. Anaesth. 105, 145-149.

Johansen, J. W., Schneider, G., Windsor, A. M., and Sebel, P. S. (1998). Esmolol potentiates reduction of minimum alveolar isoflurane concentration by alfentanil. Anesth Analg. 87, 671-676.

Koodie, L., Ramakrishnan, S., and Roy, S. (2010). Morphine suppresses tumor angiogenesis through a HIF$1\{$ alpha\}/p38mapk pathway. Am. J. Pathol. 177, 984-997.

Lam, C. F., Chang, P. J., Huang, Y. S., Sung, Y. H., Huang, C. C., Lin, M. W., Liu, Y. C., and Tsai, Y. C. (2008). Prolonged use of high-dose morphine impairs angiogenesis and mobilization of endothelial progenitor cells in mice. Anesth. Analg. 107, 686-692.

Leppert, W. (2009). Tramadol as an analgesic for mild to moderate cancer pain. Pharmacol. Rep. 61, 978-992.

Looney, M., Doran, P., and Buggy, D. J. (2010). Effect of anesthetic technique on serum vascular endothelial growth factor $\mathrm{C}$ and transforming growth factor beta in women undergoing anesthesia and surgery for breast cancer. Anesthesiology 113, 1118-1125. 
Maneckjee, R., Biswas, R., and Vonderhaar, B. K. (1990). Binding of opioids to human MCF-7 breast cancer cells and their effects on growth. Cancer Res. 50, 2234-2238.

Maneckjee, R., and Minna, J. D. (1994). Opioids induce while nicotine suppresses apoptosis in human lung cancer cells. Cell Growth Differ. 5, 1033-1040.

Martin, J. L., Charboneau, R., Barke, R. A., and Roy, S. (2010a). Chronic morphine treatment inhibits LPSinduced angiogenesis: implications in wound healing. Cell. Immunol. 265, 139-145.

Martin, J. L., Koodie, L., Krishnan, A. G., Charboneau, R., Barke, R. A., and Roy, S. (2010b). Chronic morphine administration delays wound healing by inhibiting immune cell recruitment to the wound site. Am. J. Pathol. 176, 786-799.

Mathew, B., Lennon, F. E., Siegler, J., Mirzapoiazova, T., Mambetsariev, N., Sammani, S., Gerhold, L. M., Lariviere, P. J., Chen, C. T., Garcia, J. G., Salgia, R., Moss, J., and Singleton, P. A. (2011). The novel role of the mu opioid receptor in lung cancer progression: a laboratory investigation. Anesth. Analg. 112, 558-567.

Mathiesen, O., Moiniche, S., and Dahl, J. B. (2007). Gabapentin and postoperative pain: a qualitative and quantitative systematic review, with focus on procedure. BMC Anesthesiol. 7, 6 . doi: 10.1186/1471-2253-7-6

Méric, J.-B., Rottey, S., Olaussen, K., Soria, J.-C., Khayat, D., Rixe, O., and Spano, J.-P. (2006). Cyclooxygenase2 as a target for anticancer drug development. Crit. Rev. Oncol. Hematol. 59, 51-64.

Murphy, D. F. (1993). Nsaids and postoperative pain. BMJ 306, 1493-1494.

Myles, P. S., Peyton, P., Silbert, B., Hunt, J., Rigg, J. R., and Sessler, D. I. (2011). Perioperative epidural analgesia for major abdominal surgery for cancer and recurrence-free survival: randomised trial. $B M J 342$, d1491.

O’Riain, S. C., Buggy, D. J., Kerin, M. J., Watson, R. W., and Moriarty, D. C. (2005). Inhibition of the stress response to breast cancer surgery by regional anesthesia and analgesia does not affect vascular endothelial growth factor and prostaglandin E2. Anesth. Analg. 100, 244-249.

Page, G. G., Ben-Eliyahu, S., and Liebeskind, J. C. (1994). The role of LGL/NK cells in surgery-induced promotion of metastasis and its attenuation by morphine. Brain Behav. Immun. 8, 241-250.
Page, G. G., Ben-Eliyahu, S., Yirmiya R., and Liebeskind, J. C. (1993). Morphine attenuates surgeryinduced enhancement of metastatic colonization in rats. Pain 54, 21-28.

Page, G. G., Blakely, W. P., and BenEliyahu, S. (2001). Evidence that postoperative pain is a mediator of the tumor-promoting effects of surgery in rats. Pain 90, 191-199.

Page, G. G., Mcdonald, J. S., and BenEliyahu, S. (1998). Pre-operative versus postoperative administration of morphine: impact on the neuroendocrine, behavioural, and metastatic-enhancing effects of surgery. Br. J. Anaesth. 81, 216-223.

Paice, J. (2003). "Management of the patient with pain," in Surgical Oncology: An Algorithmic Approach, eds T. Saclarides, K. Millikan, and C. Godellas (New York: SpringerVerlag), 712-720.

Palm, D., Lang, K., Niggemann, B., Drell, T. L. T., Masur, K. Zaenker, K. S., and Entschladen, F. (2006). The norepinephrine-driven metastasis development of PC-3 human prostate cancer cells in $\mathrm{BALB} / \mathrm{c}$ nude mice is inhibited by beta-blockers. Int. J. Cancer 118, 2744-2749.

Pasi, A., Qu, B. X., Steiner, R., Senn, H. J., Bar, W., and Messiha, F. S. (1991). Angiogenesis: modulation with opioids. Gen. Pharmacol. 22, 1077-1079.

Pyati, S., and Gan, T. J. (2007). Perioperative pain management. CNS Drugs $21,185-211$.

Romundstad, L., and Stubhaug, A. (2007). Glucocorticoids for acute and persistent postoperative neuropathic pain: what is the evidence? Anesthesiology 107, 371-373.

Sacerdote, P., Bianchi, M., Gaspani, L., Manfredi, B., Maucione, A., Terno, G., Ammatuna, M., and Panerai, A. E. (2000). The effects of tramadol and morphine on immune responses and pain after surgery in cancer patients. Anesth. Analg. 90, 1411-1414.

Sacerdote, P., Bianchi, M., Gaspani, L., and Panerai, A. E. (1999). Effects of tramadol and its enantiomers on concanavalin-A inducedproliferation and NK activity of mouse splenocytes: involvement of serotonin. Int. J. Immunopharmacol. 21,727-734.

Sacerdote, P., Gaspani, L., Rossoni, G., Panerai, A. E., and Bianchi, M. (2001). Effect of the opioid remifentanil on cellular immune response in the rat. Int. Immunopharmacol. 1, 713-719.
Salerno, A., and Hermann, R. (2006). Efficacy and safety of steroid use for postoperative pain relief. Update and review of the medical literature. J. Bone Joint Surg. Am. 88, 1361-1372.

Sasamura, T., Nakamura, S., Iida, Y., Fujii, H., Murata, J., Saiki, I., Noijma, H., and Kuraishi, Y. (2002). Morphine analgesia suppresses tumor growth and metastasis in a mouse model of cancer pain produced by orthotopic tumor inoculation. Eur. J. Pharmacol. 441 185-191.

Schlagenhauff, B., Ellwanger, U., Breuninger, H., Stroebel, W., Rassner, G., and Garbe, C. (2000). Prognostic impact of the type of anaesthesia used during the excision of primary cutaneous melanoma. Melanoma Res. 10, 165-169.

Shavit, Y., Ben-Eliyahu, S., Zeidel, A., and Beilin, B. (2004). Effects of fentanyl on natural killer cell activity and on resistance to tumor metastasis in rats. Dose and timing study. Neuroimmunomodulation 11 , 255-260.

Singleton, P. A., Garcia, J. G., and Moss, J. (2008). Synergistic effects of methylnaltrexone with 5fluorouracil and bevacizumab on inhibition of vascular endothelial growth factor-induced angiogenesis. Mol. Cancer Ther. 7, 1669-1679.

Singleton, P. A., Lingen, M. W., Fekete, M. J., Garcia, J. G., and Moss, J. (2006). Methylnaltrexone inhibits opiate and VEGF-induced angiogenesis: role of receptor transactivation. Microvasc. Res. 72, 3-11.

Singleton, P. A., Mambetsariev, N., Lennon, F. E., Mathew, B., Siegler, J. H., Moreno-Vinasco, L., Salgia, R., Moss, J., and Garcia, J. G. (2010). Methylnaltrexone potentiates the anti-angiogenic effects of mtor inhibitors. J. Angiogenes. Res. 2,5 .

Singleton, P. A., Moreno-Vinasco, L. Sammani, S., Wanderling, S. L., Moss, J., and Garcia, J. G. (2007). Attenuation of vascular permeability by methylnaltrexone: role of mop$\mathrm{R}$ and S1P3 transactivation. Am. $J$. Respir. Cell Mol. Biol. 37, 222-231.

Singleton, P. A., and Moss, J. (2010). Effect of perioperative opioids on cancer recurrence: a hypothesis. Future Oncol. 6, 1237-1242.

Stamer, U. M., Maier, C., Grond, S. Veh-Schmidt, B., Klaschik, E., and Lehmann, K. A. (1997). Tramadol in the management of post-operative pain: a double-blind, placebo- and active drug-controlled study. Eur. J. Anaesthesiol. 14, 646-654.
Sueoka, E., Sueoka, N., Kai, Y., Okabe, S., Suganuma, M., Kanematsu, K., Yamamoto, T., and Fujiki, H. (1998). Anticancer activity of morphine and its synthetic derivative, KT90, mediated through apoptosis and inhibition of NF-kappab activation. Biochem. Biophys. Res. Commun. 252, 566-570.

Tegeder, I., Grosch, S., Schmidtko, A., Haussler, A., Schmidt, $\mathrm{H}$. Niederberger, E., Scholich, K., and Geisslinger, G. (2003). G proteinindependent G1 cell cycle block and apoptosis with morphine in adenocarcinoma cells: involvement of p53 phosphorylation. Cancer Res. 63, 1846-1852.

Tiippana, E. M., Hamunen, K., Kontinen, V. K., and Kalso, E. (2007). Do surgical patients benefit from perioperative gabapentin/pregabalin? A systematic review of efficacy and safety. Anesth. Analg. 104, 1545-1556.

Tsai, Y. C., and Won, S. J. (2001). Effects of tramadol on T lymphocyte proliferation and natural killer cell activity in rats with sciatic constriction injury. Pain 92, 63-69.

Tsui, B., Rashiq, S., Schopflocher, D., Murtha, A., Broemling, S., Pillay, J., and Finucane, B. (2010). Epidural anesthesia and cancer recurrence rates after radical prostatectomy. Can. J. Anesth. 57, 107-112.

Ustun, F., Durmus-Altun, G., Altaner, S., Tuncbilek, N., Uzal, C., and Berkarda, S. (2010). Evaluation of morphine effect on tumour angiogenesis in mouse breast tumour model, EATC. Med. Oncol. 1-9.

Vickers, M. D., and Paravicini, D. (1995). Comparison of tramadol with morphine for post-operative pain following abdominal surgery. Eur. J. Anaesthesiol. 12, 265-271.

Wada, H., Seki, S., Takahashi, T., Kawarabayashi, N., Higuchi, H., Habu, Y., Sugahara, S., and Kazama, T. (2007). Combined spinal and general anesthesia attenuates liver metastasis by preserving $\mathrm{TH} 1 / \mathrm{TH} 2$ cytokine balance. Anesthesiology 106, 499-506.

White, P. F., Wang, B., Tang, J., Wender, R. H., Naruse, R., and Sloninsky, A. (2003). The effect of intraoperative use of esmolol and nicardipine on recovery after ambulatory surgery. Anesth. Analg. 97, 1633-1638.

Yeager, M. P., and Colacchio, T. A. (1991). Effect of morphine on growth of metastatic colon cancer in vivo. Arch Surg. 126, 454-456. 
Yeager, M. P., Procopio, M. A., Deleo, J. A., Arruda, J. L., Hildebrandt, L., and Howell, A. L. (2002). Intravenous fentanyl increases natural killer cell cytotoxicity and circulating CD16(+) lymphocytes in humans. Anesth. Analg. 94, 94-99.

Yu, S. K., Tait, G., Karkouti, K., Wijeysundera, D., Mccluskey, S., and Beattie, W. S. (2011). The safety of perioperative esmolol: a systematic review and meta-analysis of randomized controlled trials. Anesth. Analg. 112, 267-281.
Zagon, I. S., Hytrek, S. D., and Mclaughlin, P. J. (1996). Opioid growth factor tonically inhibits human colon cancer cell proliferation in tissue culture. Am. J. Physiol. 271, R511-R518.

Zagon, I. S., and Mclaughlin, P. J. (2003). Opioids and the apoptotic pathway in human cancer cells. Neuropeptides 37, 79-88.

Zagon, I. S., Roesener, C. D., Verderame, M. F., Ohlsson-Wilhelm, B. M., Levin, R. J., and Mclaughlin, P. J. (2000). Opioid growth factor regulates the cell cycle of human neoplasias. Int. J. Oncol. 17, 1053-1061.

Conflict of Interest Statement: The authors declare that the research was conducted in the absence of any commercial or financial relationships that could be construed as a potential conflict of interest.

Received: 10 May 2011; paper pending published: 30 June 2011; accepted: 25 July 2011; published online: 08 August 2011. Citation: Afsharimani B, Cabot PJ and Parat M-O (2011) Morphine use in cancer surgery. Front. Pharmacol. 2:46. doi: 10.3389/fphar.2011.00046

This article was submitted to Frontiers in Pharmacology of Anti-Cancer Drugs, a specialty of Frontiers in Pharmacology. Copyright (C) 2011 Afsharimani, Cabot and Parat. This is an open-access article subject to a non-exclusive license between the authors and Frontiers Medi $S A$, which permits use, distribution and reproduction in other forums, provided the original authors and source are credited and other Frontiers conditions are complied with. 